\title{
Genomic Heterogeneity among Human and Nonhuman Strains of Hepatitis A Virus
}

\author{
STANLEY M. LEMON,${ }^{1,2 *}$ SHIH-FONG CHAO,${ }^{2}$ ROBERT W. JANSEN,${ }^{1}$ LEONARD N. BINN,${ }^{3}$ \\ AND JAMES W. LEDUC ${ }^{4}$ \\ Division of Infectious Diseases, Department of Medicine, ${ }^{1}$ and Department of Microbiology and Immunology, ${ }^{2}$ University \\ of North Carolina at Chapel Hill, Chapel Hill, North Carolina 27514; Department of Virus Diseases, Walter Reed Army \\ Institute of Research, Washington, D.C. $20305^{3}$; and the Medical Division, U.S. Army Medical Research Institute for \\ Infectious Diseases, Fort Detrick, Frederick, Maryland $21701^{4}$
}

Received 16 July 1986/Accepted 7 November 1986

\begin{abstract}
Cloned cDNA probes derived from the P1 and P2 regions of the genome of HM175 virus, a reference strain of human hepatitis A virus (HAV), failed to hybridize under standard stringency criteria with RNA from PA21 and PA33 viruses, two epizootiologically related HAV strains recovered from naturally infected New World owl monkeys. Hybridization of these probes to PA21 RNA was only evident under reduced stringency conditions. However, cDNA representing the $5^{\prime}$ nontranslated region of the HM175 genome hybridized equally to HM175 and PA21 RNA under standard stringency conditions, while a probe derived from the $3^{\prime} 1,400$ bases of the genome yielded a reduced hybridization signal with PA21 RNA. In contrast, no differences could be discerned between HM175 virus and three other HAV strains of human origin (GR8, LV374, and MS1) in any region of the genome, unless increased stringency conditions were used. These results suggest that PA21 and PA33 are unique among HAV isolates and may represent a virus native to the owl monkey. Despite extremely poor homology within the $\mathbf{P 1}$ region, which encodes capsid polypeptides, monoclonal antibody analysis confirmed that the immunodominant neutralization epitopes of HAV were highly conserved between HM175 and PA21 viruses. Furthermore, experimental challenge of the owl monkey with successive PA33 and HM175 inocula confirmed a high but incomplete degree of cross-protection. Only one of six monkeys previously infected with PA33 developed recurrent hepatitis 28 days after intravenous HM175 challenge, while none of six monkeys previously infected with HM175 had demonstrable hepatitis following PA33 challenge. These data provide molecular evidence for the existence of HAV strains unique to nonhuman primate species and indicate that strict conservation of antigenic function may accompany substantial genetic divergence in $\mathrm{HAV}$.
\end{abstract}

Hepatitis A virus (HAV) is a hepatotrophic picornavirus with a narrow host range which includes humans and several higher primate species (14). Despite its worldwide distribution, no significant antigenic variation has been demonstrated among different strains of the virus $(16,19,23,25)$. Nonetheless, two-dimensional mapping of RNase $\mathrm{T}_{1}$ digests has demonstrated that there is significant RNA sequence heterogeneity among HAV strains (29). For several different viruses isolated directly from human feces, oligonucleotide mapping has suggested differences in 1 to $4 \%$ of nucleotide bases, while variation in up to $10 \%$ of the genome was estimated for viruses passed in nonhuman primates prior to their isolation in cell culture (29). These estimates are consistent with the degree of variation evident in nucleotide sequences of cloned viral cDNA derived from three epidemiologically distinct strains of virus $(1,20,22,27)$. Such genomic variation is not surprising given the relatively high mutation rate that is recognized to accompany the replication of RNA viruses, including picornaviruses (9).

In this report, we describe the application of cDNA-RNA hybridization to the detection of differences among five diverse strains of HAV. These studies followed the initial observation that certain cDNA probes derived from the HM175 strain of virus (27) did not hybridize to RNA from the PA33 strain of virus under standard stringency conditions. This preliminary finding was of particular interest because PA33 and the epizootiologically related PA21 strain of virus are unique among all $\mathrm{HAV}$ isolates in that they were

\footnotetext{
* Corresponding author.
}

originally recovered not from humans but from naturally infected nonhuman primates (New World owl monkeys, Aotus trivirgatus) (19). Despite this difference in origin, it has not been possible previously to distinguish these viruses from human HAV strains by any method, including quantitative measures of neutralization with homologous and heterologous antibodies $(16,19)$. While the interaction of virus with neutralizing monoclonal antibodies confirmed that epitopes involved in antibody-mediated neutralization of human HAV are highly conserved among PA33 and PA21 viruses, cDNA-RNA hybridization demonstrated that these viruses are distinct from other virus strains recovered from humans. These studies thus provide molecular evidence for the existence of HAV strains that may be indigenous to nonhuman primate species.

\section{MATERIALS AND METHODS}

HAV strains. Wild-type human HAV strains GR8 (12), LV374 (12), and MS1 (5) were purified from human fecal material. The original sources of these virus strains were the Federal Republic of Germany, Kansas, and New York, respectively. The HM175 strain of HAV, originally recovered from an infected human in Australia (8), was purified from owl monkey feces following a single passage in that species (13). PA33 strain HAV was purified from the feces of an experimentally infected owl monkey (WR149) which had been intravenously inoculated with virus recovered during a primate colony-centered epizootic outbreak in Panama (13). Three cell culture-adapted HAV variants were also examined $(4,17)$. These included HM175 virus (passage history: 
marmoset, 6 passages; African green monkey kidney (AGMK) cells, 10 passages; BS-C-1 cells, 4 passages, GR8 virus (AGMK cells, 5 passages; BS-C-1 cells, 5 passages), and PA21 virus (BS-C-1 cells, 7 passages). The PA21 virus was originally isolated from the liver of an owl monkey involved in the same epizootic as the monkey from which PA33 virus was recovered $(4,19)$, and these two strains are therefore epizootiologically closely related. Conditions for propagation of these virus strains in vitro have been described previously (4).

Virus purification. For purification of HAV from fecal materials, a $10 \%$ fecal suspension was prepared in phos-

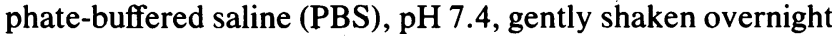
at $4^{\circ} \mathrm{C}$, and clarified by centrifugation at $1,000 \times g$ for $20 \mathrm{~min}$. Supernatant fluids from fecal suspensions or supernatant tissue culture fluids were centrifuged at $7,000 \times g$ for $30 \mathrm{~min}$ at $4^{\circ} \mathrm{C}$, and the pellets were discarded. Virus was pelleted from clarified supernatant fluids by further centrifugation at $193,000 \times g$ for $4 \mathrm{~h}$ at $4^{\circ} \mathrm{C}$ in a Beckman $50.2 \mathrm{Ti}$ rotor (Beckman Instruments, Palo Alto, Calif.) and suspended in 1 $\mathrm{ml}$ of distilled water. After sonication, $4 \mathrm{ml}$ of a solution of $\mathrm{CsCl}$ was added to obtain a final density of $1.34 \mathrm{~g} / \mathrm{cm}^{3}$, and solutions were spun at $200,000 \times g$ for $22 \mathrm{~h}$ at $4^{\circ} \mathrm{C}$ in a Beckman SW-40 rotor. Fractions (125 $\mu$ l each) were collected from the bottom of these isopycnic gradients, and 5- $\mu$ l samples of each fraction were tested for HAV antigen by radioimmunoassay. Peak fractions containing HAV (density approximately 1.32 to $1.33 \mathrm{~g} / \mathrm{cm}^{3}$ ) were pooled for further analysis.

Radioimmunoassay for HAV. HAV antigen was detected in a microtiter plate-based, solid-phase radioimmunoassay as described previously (19). This assay involves the sequential capture and detection of HAV with polyclonal antibody. For detection of unique HAV neutralization epitopes on individual strains of virus, radiolabeled murine monoclonal antibodies to HAV were allowed to bind to virus previously captured onto the solid-phase support with polyclonal antisera. Briefly, 100- $\mu$ l portions of a 1:1,000 dilution of human convalescent serum (JC), diluted in $50 \mathrm{mM}$ carbonate buffer, $\mathrm{pH}$ 9.6, were incubated in wells of flexible polyvinyl chloride microtiter plates for $4 \mathrm{~h}$ at $37^{\circ} \mathrm{C}$. The wells were washed three times with PBS containing 0.05\% Tween-80 (PBS-T), and $50-\mu 1$ portions of gradient-purified $\mathrm{HAV}$, diluted in PBS, were placed in each well. After incubation overnight at $4^{\circ} \mathrm{C}$, the wells were washed three times with PBS-T, and $50 \mu l$ of a solution containing radiolabeled monoclonal antibody (approximately $200,000 \mathrm{cpm}$ ) was added to each well. The microtiter plates were placed at $4^{\circ} \mathrm{C}$ for $4 \mathrm{~h}$ and washed five times with PBS-T, and individual wells were cut out and placed in an automatic gamma counter (LKB Rackgamma; LKB Instruments, Turku, Finland) to determine residual bound radioactivity. Monoclonal antibodies for these experiments were purified from murine ascitic fluids by precipitation in $50 \%$ ammonium sulfate and labeled by a modification of the chloramine $\mathrm{T}$ method (18) after extensive dialysis against PBS. Specific monoclonal antibodies included $\mathrm{K} 3-4 \mathrm{C} 8, \mathrm{~K} 3-2 \mathrm{~F} 2$, and $\mathrm{K} 2-4 \mathrm{~F} 2$ (21), kindly provided by I. D. Gust and A. G. Coulepis of the Fairfield Hospital, Melbourne, Australia, and B5-B3, which was the generous gift of R. S. Tedder of the Middlesex Hospital, London, U.K. Other studies have shown that these monoclonal antibodies, each of which is capable of effectively neutralizing HM175 strain HAV at high antibody dilutions, are directed against unique but closely positioned epitopes on the HM175 virion surface (26).

Radioimmunofocus assay for HAV. Cell culture-adapted

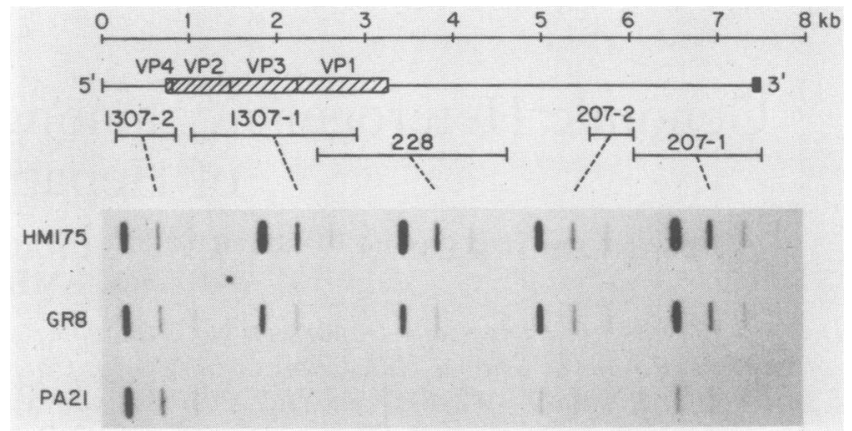

FIG. 1. RNA from three cell culture-adapted strains of HAV (HM175, GR8, and PA21) was allowed to hybridize to five cDNA probes (1307-2, 1307-1, 228, 207-2, and 207-1) derived from different regions of the HM175 virus genome. Five replicate blots were prepared by directly blotting a series of four fourfold dilutions of purified virus onto the nitrocellulose. The highest dilution of virus blotted was adjusted to yield comparable hybridization signals with each virus when hybridized with probe 1307-2 (see Table 1). The genomic map of HM175 virus is depicted at the top, along with the putative location of the regions encoding the capsid polypeptides (VP1 through VP4) and the regions represented by the five cDNA probes. Hybridization was for $22 \mathrm{~h}$ at $42^{\circ} \mathrm{C}$ in the presence of $50 \%$ formamide; the final wash temperature was $52^{\circ} \mathrm{C}$. Film was exposed for $24 \mathrm{~h}$. kb, Kilobases.

HAV was quantified by an indirect plaque assay (radioimmunofocus assay) as described previously (17). Results are presented in radioimmunofocus-forming units (RFU).

Hybridization probes. Escherichia coli cultures containing recombinant pBR322 plasmids $\mathrm{pHAV}_{\mathrm{LB}} 1307, \mathrm{pHAV}_{\mathrm{LB}} 228$, and $\mathrm{pHAV}_{\mathrm{LB}} 207$ with inserts of cDNA complementary to regions of the wild-type (marmoset passage 3) HM175 strain genome (27) were the gift of J. R. Ticehurst of the National Institute of Allergy and Infectious Diseases, Bethesda, Md. Pst I digestion fragments of plasmid DNA were prepared and purified as described previously (11). Five different cDNA fragments spanning various regions of the genome were used as hybridization probes. These included probes 1307-2 (extending from nucleotide position 162 to 848 ), 1307-1 (nucleotides 1002 to 2900 ), 228 (nucleotides 2450 to 4600 ), 207-2 (nucleotides 5550 to 6062), and 207-1 (nucleotides 6063 to 7478) (Fig. 1). ${ }^{32}$ P-labeled probes were synthesized from denatured insert DNA fragments by random priming with calf thymus oligodeoxynucleotides and $E$. coli DNA polymerase I (11). Labeled DNA was separated from the reaction mixture by chromatography through Sephadex G50 (Pharmacia, Piscataway, N.J.) and used directly for hybridization.

Blotting of HAV to nitrocellulose paper. Purified whole virion preparations were diluted into $7.5 \times \mathrm{SSC}(1 \times \mathrm{SSC}$ is $0.15 \mathrm{M} \mathrm{NaCl}$ plus $0.015 \mathrm{M}$ sodium citrate) in $4.6 \mathrm{M}$ formaldehyde and applied directly to BA85 nitrocellulose paper (Schleicher \& Schuell, Inc., Keene, N.H.) as described previously (11). After air drying for at least $30 \mathrm{~min}$, nitrocellulose papers were baked at $80^{\circ} \mathrm{C}$ in a vacuum oven for at least $2 \mathrm{~h}$. Direct blotting of whole virions in this fashion is at least as efficient as blotting of extracted RNA for detection of HAV RNA by hybridization (11).

cDNA-RNA hybridization. Hybridization was carried out as described previously (11) with modifications as indicated in Results. For comparing hybridization results between different HAV strains, the amount of each virus blotted was adjusted to achieve an equivalent signal intensity with the hybridization probe derived from the $5^{\prime}$ end of the genome 
(probe 1307-2) under standard stringency conditions. These conditions included hybridization at $42^{\circ} \mathrm{C}$ in the presence of $50 \%$ formamide, $1 \times$ Denhardt solution, $5 \times$ SSC, $0.1 \%$ sodium dodecyl sulfate (SDS), and denatured calf thymus DNA at $100 \mu \mathrm{g} / \mathrm{ml}$. Probes were boiled for $3 \mathrm{~min}$ immediately before dilution into hybridization solutions $\left(2 \times 10^{6} \mathrm{cpm} / \mathrm{ml}\right)$. Hybridization was carried out for 22 to $36 \mathrm{~h}$, after which the nitrocellulose was washed twice with $2 \times$ SSC $-0.1 \%$ SDS at room temperature for 15 to 30 min per wash and twice with $0.1 \times \mathrm{SSC}-0.1 \% \mathrm{SDS}$ at $52^{\circ} \mathrm{C}$ for 15 to $30 \mathrm{~min}$ per wash (final wash). Conditions of reduced stringency included hybridization in $40 \%$ formamide at $42^{\circ} \mathrm{C}$ followed by a final wash at $42^{\circ} \mathrm{C}$. Hybridization stringency was increased by raising the final wash temperature to 62 or $72^{\circ} \mathrm{C}$. Autoradiography was done with Kodak XAR-5 film and X-Omatic intensifying screens (Eastman Kodak Co., Rochester, N.Y.). Films were developed after exposure for 1 to 10 days at $-70^{\circ} \mathrm{C}$.

Primate challenge studies. To further assess the antigenic relatedness of the HM175 and PA33 strains of HAV, two groups of six owl monkeys, each of which had previously been infected with wild-type HM175 or PA33 virus (13), were rechallenged by intravenous inoculation of the other strain. Inocula were identical to those used previously (13). The PA33 inoculum consisted of a $0.2 \%$ fecal suspension derived from a naturally infected owl monkey involved in the primate colony-centered epizootic in Panama (19). Available data suggest that this material has an infectivity titer in owl monkeys of $>10^{6}$, infectious units per ml (3). The HM175 inoculum was a $0.2 \%$ fecal suspension derived from a naturally infected human in Australia (8) and was the generous gift of S. M. Feinstone and R. H. Purcell of the National Institute of Allergy and Infectious Diseases, Bethesda, Md. While the infectivity titer of this material has not been determined in owl monkeys, it contains approximately $10^{7}$ chimpanzee infectious units per $\mathrm{ml}$ (24). Prior to rechallenge, all monkeys were seropositive by radioimmunoassay for antibody to HAV (Havab; Abbott Laboratories, N. Chicago, Ill.) (13) and possessed neutralizing antibody to HM175 virus (15). Owl monkeys were housed as described previously (13) and, approximately 6 months after the initial experimental infection with either HM175 or PA33 viruses, were rechallenged with $1 \mathrm{ml}$ of the heterologous virus inoculum administered intravenously. Baseline serum liver enzyme activities (alanine aminotransferase [ALT] and aspartate aminotransferase $[\mathrm{AST}]$ ) and other blood chemical studies were monitored as described for the original infection of these monkeys for 2 weeks prior to rechallenge (13). Liver function tests were repeated twice weekly for 2 months following challenge with virus, and fecal samples collected during the $\mathbf{4 0}$ days following inoculation were examined by radioimmunoassay for HAV antigen. An open liver biopsy was performed for the single monkey that developed a significant enzyme elevation (greater than 2 standard deviations above the baseline ALT value). Sequential antibody titrations were not carried out because of the probability that the viral inocula contained sufficient antigenic mass to stimulate antibody production even in the absence of virus replication (3).

\section{RESULTS}

cDNA-RNA hybridization demonstrates genomic heterogeneity among HAV strains. PA21, HM175, and GR8 viruses were propagated in cell culture, and virus was purified from infected tissue culture supernatant fluids by isopycnic centrifugation. Fourfold dilutions of $\mathrm{CsCl}$ gradient fractions were blotted onto nitrocellulose and, after baking and re-
TABLE 1. Infectivity and antigen content of cell culture-derived virus yielding comparable hybridization signals with probe $1307-2$

\begin{tabular}{lcc}
\hline Virus & $\begin{array}{c}\text { Infectivity titer } \\
\left(\log _{10} \text { RFU/ml }\right)\end{array}$ & $\begin{array}{c}\text { Radio } \\
\text { immunoassay } \\
\text { titer }^{a}\end{array}$ \\
\hline HM175 & 5.79 & $1: 3.5$ \\
GR8 & 5.92 & $1: 2.6$ \\
PA21 & 5.95 & $1: 2.0$ \\
\hline
\end{tabular}

${ }^{a}$ Radioimmunoassay titer of original gradient fraction multiplied by the dilution factor.

lease of virion RNA, were hybridized with probe 1307-2 under standard stringency conditions. This probe represents approximately 700 bases near the $5^{\prime}$ end of the viral genome and spans most of the nontranslated region of the genome as well as the 5' 114 bases of the capsid-encoding region (VP4 and VP2) $(1,22,27)$. Based on this preliminary hybridization experiment, a standardized dilution of each virus preparation was selected to give equivalent hybridization signals with probe $1307-2$. The infectivity titer and antigen content of the standardized virus dilutions were remarkably similar (Table 1), suggesting an equivalent sensitivity of the 1307-2 probe for detection of these three virus strains.

To evaluate the relatedness of HM175 virus to GR8 and PA21 viruses, standardized dilutions of each virus were blotted onto multiple nitrocellulose papers as replicate blots. These blots were subsequently hybridized under identical conditions with five different HAV cDNA probes. Standard stringency conditions were used, including hybridization for $22 \mathrm{~h}$ at $42^{\circ} \mathrm{C}$ in the presence of $50 \%$ formamide and a final wash at $52^{\circ} \mathrm{C}$ in $0.1 \times \mathrm{SSC}$ (calculated to approximate $80^{\circ} \mathrm{C}$ in $1 \mathrm{M} \mathrm{Na}^{+}$and no formamide) (2). Probe 1307-2 yielded an equivalent hybridization signal with each of the three viruses (Fig. 1); however, the intensity of hybridization signals achieved with the other four probes was markedly reduced or absent when the PA21 signal was compared with the HM175 and GR8 signals. As the cDNA probes were derived from HM175 virus, this experiment indicated low or absent homology between much of the genomes of PA21 and HM175 viruses, but no detectable difference between the GR8 and HM175 viruses. The greatest degree of difference between the HM175 and PA21 viruses was apparent with the 1307-1 and 228 probes, which span much of the P1 and P2 regions of the genome (Fig. 1). The 5 ' nontranslated region of the genome (probe 1307-2) was well conserved, since similar hybridization signals were achieved with equivalent amounts of infectious virus (Table 1 ). The $3^{\prime}$ region of the genome (probes 207-2 and 207-1) had intermediate homology. Similar results were obtained in three replicate experiments. Extension of the hybridization time to $36 \mathrm{~h}$ to compensate for possible differences in the lengths of probe molecules did not alter the results. Hybridization results similar to those obtained with PA21 virus were also obtained with wild-type PA33 virus.

As a control for the blotting process, the nitrocellulose papers shown in Fig. 1 were stripped of hybridization probes by washing with $3 \times \mathrm{SSC}-50 \%$ formamide at $67^{\circ} \mathrm{C}$ for $30 \mathrm{~min}$ and then rehybridized with probe 1307-2. This second hybridization yielded identical results with each blot, indicating that the reduced hybridization signals were not related to an absence of viral RNA.

Hybridization of HM175-derived CDNA to PA21 and HM175 viruses under conditions of varied stringency. Because hybridization of probes $1307-1$ and 228 was minimal or absent with PA21 viral RNA, hybridization was repeated 


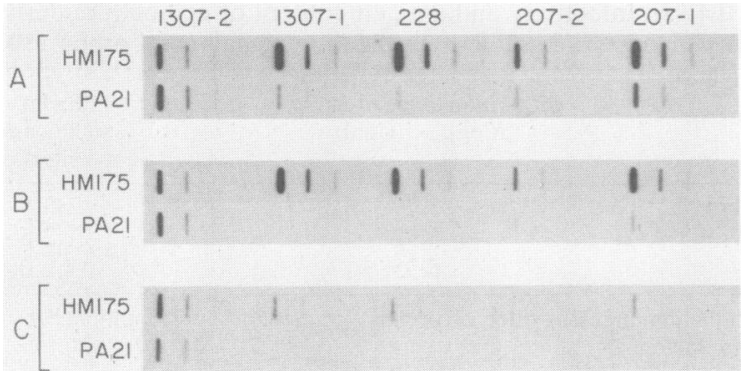

FIG. 2. Hybridization of HM175-derived cDNA probes to RNA from cell culture-adapted HM175 and PA21 viruses under conditions of varied stringency. Replicate blots were prepared as described in the legend to Fig. 1. Hybridization conditions included (A) $36 \mathrm{~h}$ at $42^{\circ} \mathrm{C}$ in the presence of $40 \%$ formamide, final wash $42^{\circ} \mathrm{C}$, (B) $36 \mathrm{~h}$ at $42^{\circ} \mathrm{C}$ in the presence of $50 \%$ formamide, final wash $52^{\circ} \mathrm{C}$, and (C) 36 $\mathrm{h}$ at $42^{\circ} \mathrm{C}$ in the presence of $50 \%$ formamide, final wash $72^{\circ} \mathrm{C}$. Films were exposed for $24 \mathrm{~h}(\mathrm{~A}$ and $\mathrm{B})$ or $72 \mathrm{~h}(\mathrm{C})$.

under conditions of reduced stringency. These conditions included hybridization for $36 \mathrm{~h}$ at $42^{\circ} \mathrm{C}$ in the presence of $40 \%$ formamide, followed by a final wash with $0.1 \times \mathrm{SSC}$ at $42^{\circ} \mathrm{C}$ (approximating $70^{\circ} \mathrm{C}$ in $1 \mathrm{M} \mathrm{Na}^{+}$and no formamide). Under these conditions, all five probes hybridized to the PA21 virus, but hybridization signals were lower than with HM175 for all but probe 1307-2 ( $5^{\prime}$ domain) (Fig. 2A). Higher-stringency conditions were also examined, including hybridization for $36 \mathrm{~h}$ at $42^{\circ} \mathrm{C}$ in the presence of $50 \%$ formamide, followed by a final high-stringency wash with $0.1 \times \mathrm{SSC}$ at $72^{\circ} \mathrm{C}$ (approximating $100^{\circ} \mathrm{C}$ in $1 \mathrm{M} \mathrm{Na}^{+}$and no formamide) (Fig. 2C). Hybridization was apparent only with probe 1307-2 under these conditions, and signal intensities were reduced with both HM175 and PA21 viruses. The reduction in signal was equivalent with both viruses, indicating an absence of detectable difference in sequence homology within this region of the genome.

To determine whether the hybridization of probe 1307-2 to RNA from PA21 virus was due entirely to sequence homology within the nontranslated region of the genome, the 1307-2 DNA fragment was digested with $X b a I$ to yield a 105-base-pair fragment extending from positions 745 to 849 and representing the extreme $5^{\prime}$ end of the open reading frame. The probe prepared from this DNA fragment hybridized with RNA of both HM175 and PA21 viruses and yielded approximately similar hybridization signals with each virus under standard stringency conditions (Fig. 3A). Thus, regions of homology permitting hybridization of HM175 cDNA to PA21 RNA extend into the region of the genome encoding VP4 and VP2. However, hybrids formed with the $X b a I$

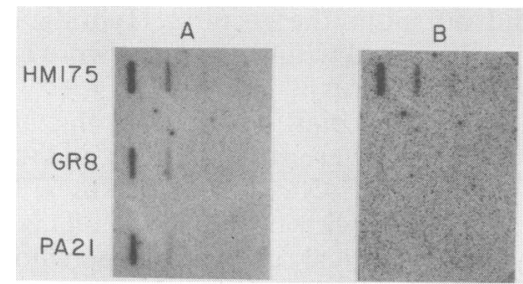

FIG. 3. Blots were prepared as described in the legend to Fig. 1 and hybridized with an $\mathrm{XbaI}$ fragment of 1307-2 representing base positions 745 to 849 in the HM175 virus genome (extreme 5' end of the large open reading frame). Hybridization was carried out over 22 $h$ at $42^{\circ} \mathrm{C}$ in the presence of $50 \%$ formamide, with a final wash at $52^{\circ} \mathrm{C}$ (A) or $62^{\circ} \mathrm{C}$ (B). Films were exposed for $24 \mathrm{~h}(\mathrm{~A})$ or $72 \mathrm{~h}(\mathrm{~B})$.

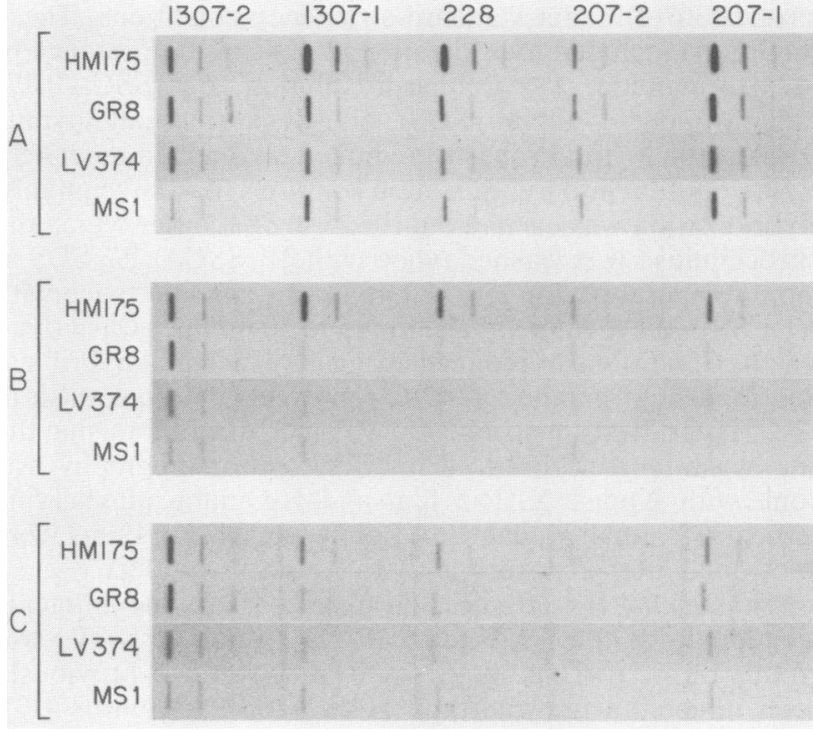

FIG. 4. Hybridization of HM175-derived cDNA probes to RNA from four wild-type human viruses (HM175 virus had gone through one passage in an owl monkey). Experimental details were as described in the legend to Fig. 1. Hybridization was carried out for $22 \mathrm{~h}$ at $42^{\circ} \mathrm{C}$ in the presence of $50 \%$ formamide. Final wash temperatures were (A) $52^{\circ} \mathrm{C}$, (B) $62^{\circ} \mathrm{C}$, and (C) $72^{\circ} \mathrm{C}$. Films were exposed for $24 \mathrm{~h}$ (A and B) or $72 \mathrm{~h}(\mathrm{C})$.

fragment and PA21 RNA were less stable than HM175 hybrids when subjected to a final wash in $0.1 \times \mathrm{SSC}$ at $62^{\circ} \mathrm{C}$ (approximating $90^{\circ} \mathrm{C}$ in $1 \mathrm{M} \mathrm{Na}^{+}$), indicating that the degree of homology within this region is lower than that within the $5^{\prime}$ nontranslated region of the genome (cf. Fig. 3B with Fig. $2 \mathrm{C}$ and $4 \mathrm{~B}$, below).

Comparison of four wild-type human HAV strains by cDNA-RNA hybridization. Because the results shown in Fig. 1 suggested that HM175 and GR8 viruses had significantly greater homology than HM175 and PA21 viruses, it was of interest to examine other human strains of virus. Wild-type viruses were used for this analysis; HM175 virus was purified from the feces of an experimentally infected owl monkey (virus passed once in the owl monkey), while GR8, LV374, and MS1 viruses were purified directly from human specimens. The blotted dilutions of virus were standardized as before to yield equivalent hybridization signals with probe 1307-2, and replicate blots were hybridized against the five HM175-derived cDNA probes under standard stringency conditions. These experiments revealed no significant differences between the four wild-type human viruses (HM175, GR8, LV374, and MS1) (Fig. 4A) or between wild-type and cell culture-adapted virus variants (HM175 and GR8). The absence of differences among these human strains contrasts with the results obtained with the owl monkey isolates (Fig. 1 and 2) and suggests that the PA21 and PA33 viruses are unique.

To determine whether differences could be detected between human virus strains under increased conditions of stringency, the blots shown in Fig. $4 \mathrm{~A}$ were washed at $62^{\circ} \mathrm{C}$ with $0.1 \times$ SSC and reexposed for autoradiography. Under these conditions, HM175 virus RNA could be distinguished from RNA from the GR8, LV374, and MS1 viruses (Fig. 4B). However, as noted with HM175 and PA21 viruses, the domain represented by probe 1307-2 was relatively well conserved, because cDNA-RNA hybrids formed with probe 


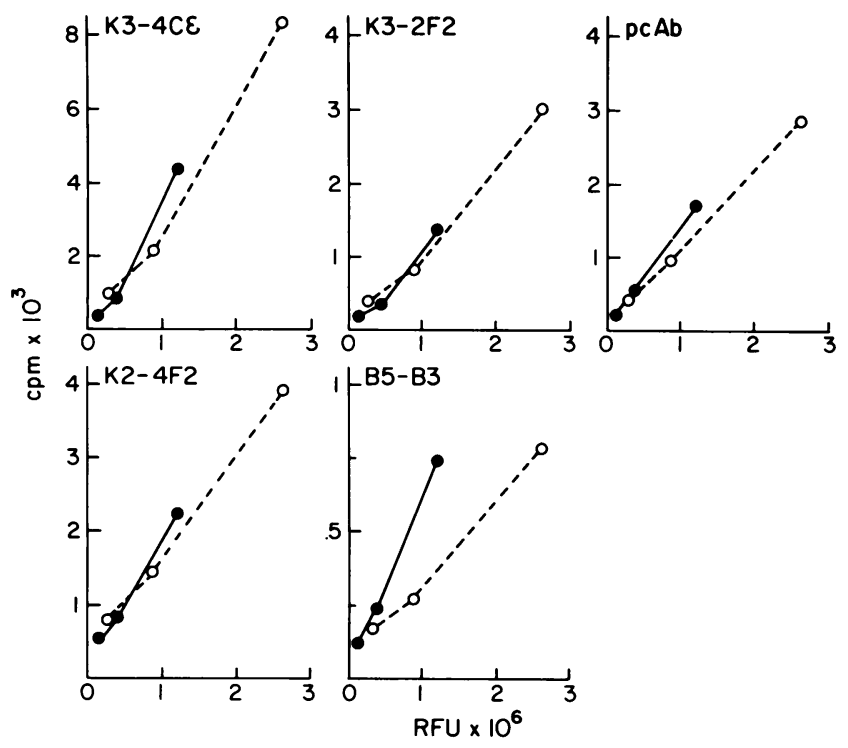

FIG. 5. Monoclonal antibody analysis of HM175 (-) and PA21 (- - ) viruses. Dilutions of gradient-purified virus were allowed to bind to polyclonal human antibody fixed on a solid-phase support. Immobilized virus was then exposed to radiolabeled monoclonal antibodies (K2-4F2, K3-2F2, K3-4C8, and B5-B3) or polyclonal antibodies $(\mathrm{pcAb})$. Virus quantities present in each dilution were estimated by radioimmunofocus assay of the original gradient fractions.

1307-2 were more stable than those formed with the other probes. Following a further wash at $72^{\circ} \mathrm{C}$, a marked reduction in hybridization signals was noted with all the virus strains, including the homologous HM175 virus (Fig. 4C).

Neutralization epitopes are conserved between HM175 and PA21 viruses. Because genomic variation between HM175 and PA21 viruses was maximal within the P1 region of the genome (Fig. 1), the antigenic characteristics of these viruses were examined by determining the ability of several murine monoclonal antibodies (K3-4C8, K3-2F2, K2-4F2 [21], and B5-B3) to bind to specific neutralization epitopes on each virus strain. These monoclonal antibodies have high-titer neutralizing activity (15) and are directed against unique but closely positioned or overlapping epitopes on the HM175 virus capsid (26). The degree to which radiolabeled monoclonal antibodies bound to different quantities of virus fixed to a solid-phase support was assessed (Fig. 5). Neutralization epitopes recognized by all four monoclonal antibodies were present on both viruses. Furthermore, there was little difference in the relative avidity of the radiolabeled antibodies for the two virus preparations, except for B5-B3, which bound more avidly to HM175 virus. These experiments confirmed that only a minor degree of antigenic variation exists between these two strains of virus, despite the poor homology evident within the P1 region which encodes the capsid proteins.

Cross-protection between HM175 and PA33 viruses in the owl monkey. Twelve owl monkeys which had been previously infected with either HM175 or PA33 viruses (six monkeys each) (13) were rechallenged with heterologous virus to determine the level of whole-animal cross-protection following these virus infections. All monkeys were seropositive by radioimmunoassay for antibody to HAV prior to their second viral challenge. Over a 2-month period following the intravenous inoculation of the heterologous challenge virus, only 1 of 12 monkeys developed recurrent hepatitis (Table 2). This monkey (WR-130) was infected with PA33 virus 6 months prior to challenge with HM175 virus. Twenty-eight days after rechallenge, the monkey had recurrence of elevated serum ALT and AST activities, but to a lesser degree than with the primary PA33 infection (Fig. 6). A comparison of serial liver biopsies performed 43 days before and 28 days after inoculation of HM175 virus revealed new changes consistent with acute viral hepatitis, including lobular mononuclear cell infiltration and hepatocellular necrosis. Changes were more pronounced than those occurring during the primary PA33 infection, but this could be attributable to differences in the timing of the biopsy with respect to the period of enzyme elevation. Fecal shedding of viral antigen was not detected by radioimmunoassay in any monkey during the rechallenge period. cDNA-RNA hybridization failed to detect fecal shedding of HM175 virus by animal WR-130 before or during the period of enzyme elevation.

\section{DISCUSSION}

Although isolated from different primate species, the human HM175 and simian PA21 strains of HAV are closely related antigenically. A previous cross-neutralization analysis of these viruses demonstrated less than a fourfold difference in the ability of heterologous and homologous postinfection polyclonal antisera to neutralize each virus (16). Moreover, the viruses share immunodominant neutralization epitopes (Fig. 5), and infection of the owl monkey with either virus provides high, although incomplete, protection against later rigorous intravenous challenge with the other virus (Table 2). Despite these antigenic similarities, cDNA probes derived from the $\mathrm{P} 1$ and $\mathrm{P} 2$ regions of the HM175 genome failed to hybridize to PA21 virus RNA under conditions of normal stringency (Fig. 1). These probes included 1307-1 and 228 , which together span a 3.6-kilobase region near the $5^{\prime}$ end of the translated region of the genome and thus are complementary to the region of the HAV genome that encodes the HAV capsid proteins (nucleotides 735 to 3245 ) $(1,20,22)$. VP1, the major surface protein of HAV, has been mapped to nucleotides 2208 to 3245 (1) and shown to contain at least part of a dominant neutralization immunogenic site on the virion surface (10). This neutralization site includes epitopes bound by the monoclonal antibodies used in the experiment shown in Fig. 5 (26). Thus, comparison of the HM175 and PA21 viruses provides a striking example of strict retention of antigenic function despite major divergence in the nucleotide sequence of an RNA virus.

Despite the poor homology evident between the P1 and P2 regions of the HM175 and PA21 virus genomes, the 5' terminus (up to base 849 ) remains relatively well conserved. The enhanced temperature stability of cDNA-RNA hybrids formed in this region may be related in part to the greater $\mathrm{G}+\mathrm{C}$ content of the $5^{\prime}$ nontranslated sequences (nucleotides 1 to 734$)$ compared with the remainder of the genome $(1,22)$. However, hybridization did not reveal differences between strains of $\mathrm{HAV}$ within the $5^{\prime}$ noncoding region of the genome even when carried out under very stringent conditions which probably exceeded the $T_{m}$ of the cDNA-RNA hybrids (Fig. $2 C)$. The conservation apparent within this region of the HAV genome may reflect tighter biological constraints on sequence variation. The secondary structure of the nontranslated RNA may have special importance, although our understanding of the function of this genomic region remains speculative. These results indicate that genomic heterogeneity among strains of HAV resembles genetic 
TABLE 2. Cross-protection between HM175 and PA33 viruses in the owl monkey ${ }^{a}$

\begin{tabular}{|c|c|c|c|c|c|c|c|c|}
\hline \multirow{2}{*}{$\begin{array}{c}\text { Owl } \\
\text { monkey } \\
\text { no. }\end{array}$} & \multicolumn{4}{|c|}{ First challenge } & \multicolumn{4}{|c|}{ Second challenge } \\
\hline & Virus & $\begin{array}{l}\text { Peak ALT } \\
\text { (day) }\end{array}$ & $\begin{array}{c}\text { Virus } \\
\text { shedding }\end{array}$ & $\begin{array}{c}\text { Liver } \\
\text { biopsy }\end{array}$ & Virus & $\begin{array}{c}\text { Peak ALT } \\
\text { (day) }\end{array}$ & $\begin{array}{c}\text { Virus } \\
\text { shedding }\end{array}$ & $\begin{array}{c}\text { Liver } \\
\text { biopsy }\end{array}$ \\
\hline WR-68 & PA33 & 16 & + & + & HM175 & - & - & ND \\
\hline WR-80 & PA33 & 21 & + & + & HM175 & - & - & ND \\
\hline WR-130 & PA33 & 21 & + & + & HM175 & 39 & - & + \\
\hline WR-148 & PA33 & 28 & + & + & HM175 & - & - & ND \\
\hline WR-149 & PA33 & 21 & + & - & HM175 & - & - & ND \\
\hline WR-153 & PA33 & 21 & + & + & HM175 & - & - & ND \\
\hline E-4 & HM175 & 25 & + & + & PA33 & - & - & ND \\
\hline $\mathrm{N}-2$ & HM175 & 39 & + & ND & PA33 & - & - & ND \\
\hline $\mathrm{N}-3$ & HM175 & 35 & + & + & PA33 & - & - & ND \\
\hline WR-154 & HM175 & 43 & + & + & PA33 & - & - & ND \\
\hline WR-155 & HM175 & 32 & + & + & PA33 & - & - & ND \\
\hline WR-204 & HM175 & - & - & ND & PA33 & - & - & ND \\
\hline
\end{tabular}

${ }^{a}$ Monkeys rechallenged with HM175 virus were inoculated 184 days after primary PA33 challenge, while those rechallenged with PA33 were inoculated 254 days after primary HM175 challenge. The day of peak serum ALT elevation is shown ( - , no values higher than 2 standard deviations above the mean of that individual monkey's baseline values). Liver biopsies were performed when ALT values were elevated (+, histopathologic findings of acute viral hepatitis). ND, Not done.

differences among the coxsackie B virus group in that there is a high degree of conservation among $5^{\prime}$ nontranslated sequences (28). However, in contrast to HAV, genomic heterogeneity within the capsid-encoding region of the coxsackie B virus genome is associated with substantial antigenic variation. The $3^{\prime}$ ends of the HM175 and PA21 virus genomes have a degree of homology which is intermediate between that of the $5^{\prime}$ and central domains, as indicated by weak hybridization with probes which span the 3'terminal 1,900 bases (Fig. 1). This region encodes the putative HAV polymerase and includes a short, nontranslated $3^{\prime}$ sequence as well $(1,22,27)$.

The degree of nucleotide homology between HM175 and
PA21 viruses cannot be accurately estimated from the results shown in Fig. 1 and 2. Few data are available on which to base an estimate of sequence variation from the thermal stabilities of DNA-RNA hybrids in a filter hybridization system. Furthermore, small regions of base-matching could mask larger regions lacking homology, depending on the lengths of individual probe molecules and the distribution of mismatches within the target genomes. Nonetheless, the data presented in Fig. 2 suggest that the $T_{m}$ of hybrids formed with probes $1307-1$ or 228 and RNA from HM175 or PA21 viruses differs by more than $20^{\circ} \mathrm{C}$. Extrapolating from studies with DNA-DNA hybrids, this would suggest presence of at least 20 to $40 \%$ base mismatches in these regions

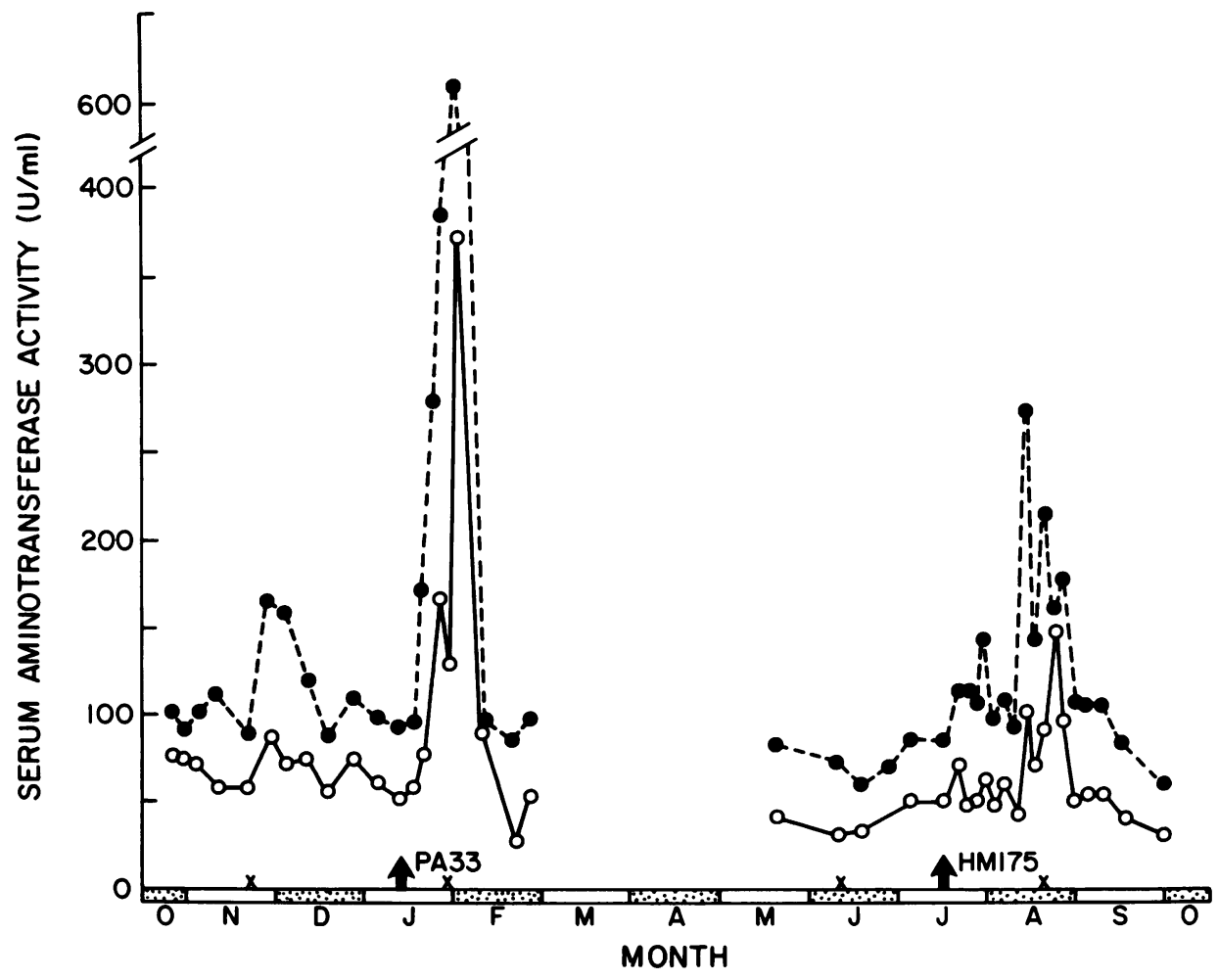

FIG. 6. Serum aminotransferase activities in an owl monkey (WR-130) following primary challenge with PA33 virus and rechallenge with HM175 virus 6 months later (arrows). Symbols: __, ALT; - - , AST; $\times$, percutaneous liver biopsy time points. 
of the HM175 and PA21 genomes (2). However, sequencing of cloned cDNA will be necessary to establish the precise degree of relatedness between the PA21 and HM175 genomes. Such studies will also reconcile differences between the genetic and antigenic comparison of these viruses. Poor hybridization with cDNA probes representative of RNA encoding the highly conserved, immunodominant neutralization epitopes of HAV may be due to the presence of very short yet highly conserved RNA sequences, third base changes not affecting the amino acid sequence of the protein, or substantial amino acid alterations within antibody-binding sites which do not affect antigenicity (structural conservation).

The data presented in Fig. 4 suggest that the $T_{m}$ of cDNA-RNA hybrids formed with HM175 cDNA and RNA from human strains of HAV (GR8, LV374, and MS1) are much closer to the $T_{m}$ s of HM175 hybrids and probably differ by approximately $10^{\circ} \mathrm{C}$. While these values were not precisely determined, the hybridization results are consistent with the 1 to $10 \%$ variation in the nucleotide sequences of various human HAV strains that has been indicated by oligonucleotide mapping (29) and a comparison of the sequences of cloned cDNA from various strains $(1,20,22,27)$. Such differences are of course in accord with the general notion that RNA viruses are subject to high mutation rates due to the absence of a proof reading function in viral RNA synthesis (9). Taken together, however, the results shown in Fig. 2 and 4 indicate that the degree of genetic variation existing between the HM175 and PA21 viruses is much greater than that existing between HM175 and the three other HAV strains recovered from humans in diverse geographic locations. These hybridization studies thus suggest that PA21 and PA33 viruses may represent a unique virus that is indigenous to the owl monkey.

Initial speculation concerning the origin of the PA21 and PA33 viruses recovered from owl monkeys in the Panamanian primate colony centered on the possibility that the virus originally entered the colony from an infected human, as only a very small proportion of newly captured owl monkeys in Panama $(<2 \%)$ possess antibody to HAV upon capture (19). In other studies, however, variable proportions of several different primate species have been found to be seropositive for antibody to $\mathrm{HAV}$ at some time following capture $(6,7)$. This has generally been assumed to reflect infection of these primates with human virus following contact with humans. However, Burke and Heisey (6) have proposed a "sylvatic cycle" for HAV among cynomolgus monkeys in Malaysia, as the prevalence of antibody found among newly captured cynomolgus monkeys trapped in jungle regions far from human habitations has been highly correlated with weight and thus with age. The age-related nature of seroprevalence among cynomolgus monkeys in Malaysia is similar to that found among human populations and strongly suggests that virus is transmitted in the wild. The finding of an apparently unique virus strain among owl monkeys in Panama lends support to this hypothesis and suggests that there may be a number of such strains unique to other primate species. If so, the ecology of HAV may be substantially more complex than previously recognized.

Despite poor homology in the $\mathrm{P} 1$ and $\mathrm{P} 2$ regions of the genome, it is certain that the PA21 and PA33 viruses have a common ancestry with HM175 virus, given the conservation apparent within the $5^{\prime}$ nontranslated RNA and their close immunologic relatedness. It is remarkable that 11 of 12 monkeys previously infected with one of these virus strains failed to develop hepatitis or shed detectable quantities of virus following an intravenous challenge with a large amount of the heterologous virus. Recent studies suggest that HAV possesses a highly conserved, immunodominant site on the capsid surface that is responsible for induction of neutralizing antibody (26). This site includes several distinct neutralization epitopes, including those recognized by the monoclonal antibodies used in the experiments depicted in Fig. 5. The retention of this antigenic structure despite substantial genetic divergence supports the concept that this functional site must play a fundamental role in the pathogenesis of hepatitis $\mathrm{A}$ and is thus essential for survival of the virus in vivo.

\section{ACKNOWLEDGMENTS}

We are grateful to J. R. Ticehurst for his gift of $E$. coli cultures containing recombinant plasmids and to A. G. Coulepis, I. D. Gust, and R. S. Tedder for their generous gifts of monoclonal antibodies. We also thank C. M. Keenan and C. Trahan for assistance with the primate challenge studies and J. N. Newbold for frequent and helpful discussions.

This study was supported in part by contract DAMD-17-85C-5272 from the U.S. Army Medical Research and Development Command and by a Technical Services Agreement with the World Health Organization Programme for Vaccine Development.

\section{LITERATURE CITED}

1. Baroudy, B. M., J. R. Ticehurst, T. A. Miele, J. V. Maizel, R. H. Purcell, and S. M. Feinstone. 1985. Sequence analysis of hepatitis A virus cDNA coding for capsid proteins and RNA polymerase. Proc. Natl. Acad. Sci. USA 82:2143-2147.

2. Beltz, G. B., K. A. Jacobs, T. H. Eickbush, P. T. Cherbas, and F. C. Kafatos. 1983. Isolation of multigene families and determination of homologies by filter hybridization methods. Methods Enzymol. 100:266-285.

3. Binn, L. N., W. H. Bancroft, S. M. Lemon, R. H. Marchwicki, J. W. LeDuc, C. J. Trahan, E. C. Staley, and C. M. Keenan. 1986. Preparation of a prototype inactivated hepatitis A virus vaccine from infected cell cultures. J. Infect. Dis. 153:749-756.

4. Binn, L. N., S. M. Lemon, R. H. Marchwicki, R. R. Redfield, N. L. Gates, and W. H. Bancroft. 1984. Primary isolation and serial passage of hepatitis A virus strains in primate cell cultures. J. Clin. Microbiol. 20:28-33.

5. Boggs, J. D., J. L. Melnick, M. E. Conrad, and B. F. Felsher. 1970. Viral hepatitis: clinical and tissue culture studies. J. Am. Med. Assoc. 214:1041-1046.

6. Burke, D. S., and G. B. Heisey. 1984. Wild Malaysian cynomolgus monkeys are exposed to hepatitis A virus. Am. J. Trop. Med. Hyg. 33:940-944.

7. Eichberg, J. W., and S. S. Kalter. 1980. Hepatitis A and B: serological survey of human and nonhuman primate sera. Lab. Anim. Sci. 30:541-543.

8. Gust, I. D., N. I. Lehmann, S. Crowe, M. McCrorie, S. A. Locarnini, and C. R. Lucas. 1985. The origin of the HM175 strain of hepatitis A virus. J. Infect. Dis. 151:365-367.

9. Holland, J., K. Spindler, F. Horodyski, E. Grabau, S. Nichol, and S. Van de Pol. 1982. Rapid evolution of RNA genomes. Science 215:1577-1585.

10. Hughes, J. V., L. W. Stanton, J. E. Tomassini, W. J. Long, and E. M. Scolnick. 1984. Neutralizing monoclonal antibodies to hepatitis A virus: partial localization of a neutralizing antigenic site. J. Virol. 52:465-473.

11. Jansen, R. W., J. E. Newbold, and S. M. Lemon. 1985. Combined immunoaffinity cDNA-RNA hybridization assay for detection of hepatitis A virus in clinical specimens. J. Clin. Microbiol. 22:984-989.

12. Lednar, W. M., S. M. Lemon, J. W. Kirkpatrick, R. R. Redfield, M. L. Fields, and P. W. Kelley. 1985. Frequency of illness associated with hepatitis A virus infection in adults. Am. J. Epidemiol. 122:226-233.

13. LeDuc, J. W., S. M. Lemon, C. M. Keenan, R. R. Graham, R. H. Marchwicki, and L. N. Binn. 1983. Experimental infection 
of the New World owl monkey (Aotus trivirgatus) with hepatitis A virus. Infect. Immun. 40:766-772.

14. Lemon, S. M. 1985. Type A viral hepatitis: new developments in an old disease. N. Engl. J. Med. 313:1059-1067.

15. Lemon, S. M., and L. N. Binn. 1983. Serum neutralizing antibody response to hepatitis $\mathrm{A}$ virus. J. Infect. Dis. 148:1033-1039.

16. Lemon, S. M., and L. N. Binn. 1983. Antigenic relatedness of two strains of hepatitis A virus determined by crossneutralization. Infect. Immun. 42:418-420.

17. Lemon, S. M., L. N. Binn, and R. H. Marchwicki. 1983. Radioimmunofocus assay for quantitation of hepatitis A virus in cell culture. J. Clin. Microbiol. 17:834-839.

18. Lemon, S. M., C. D. Brown, D. S. Brooks, T. E. Simms, and W. H. Bancroft. 1980. Serum immunoglobulin M response to hepatitis A virus determined by solid-phase radioimmunoassay. Infect. Immun. 28:927-936.

19. Lemon, S. M., J. W. LeDuc, L. N. Binn, A. Escajadillo, and K. G. Ishak. 1982. Transmission of hepatitis A virus among recently captured Panamanian owl monkeys. J. Med. Virol. 10:25-36.

20. Linemeyer, D. L., J. G. Menke, A. Martin-Gallardo, J. V. Hughes, A. Young, and S. W. Mitra. 1985. Molecular cloning and partial sequencing of hepatitis A viral cDNA. J. Virol. 54:247-255.

21. MacGregor, A., M. Kornitschuk, J. G. R. Hurell, N. I. Lehmann, A. G. Coulepis, S. A. Locarnini, and I. D. Gust. 1983 Monoclonal antibodies against hepatitis A virus. J. Clin. Microbiol. 18:1237-1243.
22. Najarian, R., D. Caput, W. Gee, S. J. Potter, A. Renard, J. Merryweather, G. Van Nest, and D. Dina. 1985. Primary structure and gene organization of human hepatitis A virus. Proc. Natl. Acad. Sci. USA 82:2627-2631.

23. Provost, P. J., O. L. Ittensohn, V. M. Villarejos, J. A. Arguedas, and M. R. Hilleman. 1977. Etiologic relationship of marmosetpropagated CR326 hepatitis A virus to hepatitis in man. Proc. Soc. Exp. Biol. Med. 142:1257-1267.

24. Purcell, R. H., S. M. Feinstone, J. R. Ticehurst, R. J. Daemer, and B. M. Baroudy. 1985. Hepatitis A virus, p. 9-22. In G. N. Vyas, J. L. Dienstag, and J. H. Hoofanagle (ed.), Viral hepatitis and liver disease. Grune and Stratton, Inc., Orlando, Fla.

25. Rakela, J., O. H. Fay, D. Stevenson, I. Gordon, and J. W. Mosley. 1976. Similarities of two hepatitis A virus strains. Bull. W.H.O. 54:561-564.

26. Stapleton, J. T., and S. M. Lemon. Neutralization escape mutants define a single dominant immunogenic neutralization site on hepatitis A virus. J. Virol. 61:491-498.

27. Ticehurst, J. R., V. R. Racaniello, B. M. Baroudy, D. Baltimore, R. H. Purcell, and S. M. Feinstone. 1983. Molecular cloning and characterization of hepatitis A virus cDNA. Proc. Natl. Acad. Sci. USA 80:5885-5889.

28. Tracey, S. 1984. A comparison of genomic homologies among the coxsackievirus B group: use of fragments of the cloned coxsackievirus B3 genome as probes. J. Gen. Virol. 65: 2167-2172.

29. Weitz, M., and G. Siegl. 1985. Variation among hepatitis A virus strains. I. Genomic variation detected by $\mathrm{T} 1$ oligonucleotide mapping. Virus Res. 4:53-67. 